Article

\title{
The Water Abstraction License Regime in Italy: A Case for Reform?
}

\author{
Silvia Santato ${ }^{1,2, *}$, Jaroslav Mysiak ${ }^{1,2}$ and Carlos Dionisio Pérez-Blanco 1,2 \\ 1 Euro-Mediterranean Centre on Climate Change, Isola di S. Giorgio Maggiore 8, 30124 Venice, Italy; \\ jaroslav.mysiak@cmcc.it (J.M.); dionisio.perez@feem.it (C.D.P.B.) \\ 2 Fondazione Eni Enrico Mattei, Isola di S. Giorgio Maggiore 8, 30124 Venice, Italy \\ * Correspondence: silvia.santato@feem.it; Tel.: +39-041-2700467
}

Academic Editor: Tim Smith

Received: 7 December 2015; Accepted: 7 March 2016; Published: 15 March 2016

\begin{abstract}
The current Water Abstraction License (WAL) regime in Italy is no longer flexible enough to cope with the challenges posed by human-induced climate and global environmental changes. The cornerstones of the current regime were laid down in the 1930s and have remained essentially unchanged ever since. The sole noteworthy reform of the Italian WAL regime was the decentralization of the regulatory competences from the state to the regional authorities in the late 1990s. In this paper, we review the WAL regimes across the administrative regions comprising the Po River Basin District (PRBD), the largest and economically most important in Italy. PRBD's WAL regime includes a rigid and scattered WAL normative that hinders the performance of bottom-up conflict resolution mechanisms at a basin scale; a water pricing scheme that does not reflect the cost of water conveyance and use, and does not encourage efficient water allocation; and the lack of a central WAL register, which delays and in some cases impedes an environmental impact assessment for issuing new licenses or renewing existing ones, and does not allow prioritizing applications according to their full economic value. We argue these deficiencies may compromise both the integrity of riverine and water dependent ecosystems and the economic uses of water. This paper offers insights that can inform reform of water allocations in the PRBD and elsewhere in Italy and in Europe.
\end{abstract}

Keywords: water abstractions license; water fee; water security; Po River Basin District

\section{Introduction}

Water scarcity, along with more frequent and severe droughts, are threats that may undo the efforts to achieve the good ecological status of the European water bodies [1], and short-circuit the performance of a wide array of sectors driving economic growth [2]. The financial crisis of the past decade has revealed a high exposure of the EU to economic shocks, including that of extreme weather and climate-related hazards, exacerbated by fiscal and "other macro-economic imbalances" [3]. The European Climate Adaptation Strategy [4] has diagnosed that the risk posed to water security [5] will make up the bulk of the expected climate change environmental and economic impacts. However, the mitigation of water scarcity and droughts is but the last among the aims declared in Article 1 of the Water Framework Directive (WFD) [1], and the least substantiated. The issues of water scarcity and droughts have been further addressed in the EC Communication on water scarcity and droughts [6], which has identified a more efficient water allocation among the seven European concerted actions. Efficient water use is also a cornerstone of the EU Resource Efficiency Flagship initiative, as a part of the Europe 2020 Strategy. The EU Water Policy Review [2,7] has noted some progress, though as yet insufficient, in drought management in Europe, and in the application of economic principles (e.g., cost recovery and water pricing). It has encouraged, cautiously, the use of market mechanisms (e.g., the water right trading scheme) where this represents a value-added increase [2]. Along with this process, 
the European Parliament (EP) has recommended on several occasions a targeted European policy on water scarcity and droughts [8].

There is reason to believe that, along with the growing demand for water, the effects of the water supply crisis induced by climate change will become particularly pronounced in Southern Europe [5,9,10], and especially in Italy [11]. It is widely accepted that the most effective and efficient ways of adapting to amplified scarcity and droughts are a combination of economic instruments (e.g., insurance, and water pricing and trading) along with legislation and regulation in order to plan more successfully for scarcity and drought spells $[2,5,12]$. The successful implementation of proactive water management instruments such as those listed above demands flexible, consistent and sustainable Water Abstraction License (WAL) regimes [13-17]. Some EU Member States, most notably Spain and UK, have already started a reform of WAL regimes to address this need.

Water abstraction permits in England and Wales were regulated by the Water Act of 1963 [18]. The permits took into little or no consideration what level of abstraction the water body could actually supply and the allocation system has since proved to be unsustainable. Current abstraction levels are causing significant ecological problems in over 1000 river water bodies [19] and $42 \%$ of groundwater bodies are failing [20]. The Water Resources Act of 1991 delegated the task of issuing abstraction licenses to the Environment Agency [21]. The payment of a fixed fee proceeds with the application whose amount is stated in the Abstraction Charges Scheme collected by the Environment Agency (EA). There are three types of licenses: a full license $\left(>20 \mathrm{~m}^{3} /\right.$ day); a temporary license $\left(<20 \mathrm{~m}^{3} /\right.$ day over a period of less than 28 days); and a transfer license (trading of full licenses). Only full licenses are charged the fixed fee by the Environment Agency(as of 2015, the minimum annual charge for full licenses is $£ 25.00$ ) [22]. All new abstraction licenses granted after April 2004 are required to include a time limit of typically 12 years. Temporary and permanent water trading for the whole or part of the WAL are possible but typically require the parties involved to apply to the Environment Agency for a new license and to change or cancel (revoke) any existing license. The current WAL regime has proved inadequate in coping with growing challenges. A reform has been recommended in the Cave Report [23] and supported by the analysis of the Water Service Regulation Authority (OFWAT) and the EA. The reform, announced in the Natural Environment White Paper [24] and further substantiated in the Department for Environment Food \& Rural Affairs (DEFRA) [25,26], introduces a transition to a new regime by the 2020s. The scope of the reform is to install flexible and sustainable tradable licensing regime capable to respond to current and future challenges.

In Spain, water has been managed within hydrological units ever since the River Basin District Authorities (RBDAs) were instituted back in 1926. The water license holders are granted the right to abstract and use water of specified volumes and for specific purposes. Water is public, and only a fraction of groundwater resources is privately owned [27]. WALs are awarded, supervised and managed by RBDAs, which can limit abstractions either temporarily or permanently, e.g., to meet environmental regulations. Water charges are exerted through a regulation fee (in Spanish: canon de regulación, charges for the abstraction and storage costs of surface water), a water use tariff (in Spanish: tarifa de utilización de agua, charges for the transportation costs of surface water), sanitation and treatment tariffs, and additional contributions raised by water user boards (e.g., irrigation communities) $[27,28]$. The 1999 reform of the Water Law allowed for trading of water entitlements [28]. Successive reforms have designated a more flexible WAL regime that is able to channel water abstractions towards economically more efficient uses [27-29]. The RBDA may not authorize the trading deal in the case of conflicts with pre-existing uses, although the rule of positive administrative silence applies [30].

In Italy, the WAL regime is tortuous and substandard, reflecting a Byzantine interplay of water institutions [31]. An abstraction license is required under the Royal Decree (R.D.) n ${ }^{\circ} 1775$ of 1933 [32] for the abstraction of surface waters (such as from rivers, streams and canals) and groundwater. Since then the regime has evolved through a process of political decentralization and devolution of environmental protection [33]. As a result, the regional administrations (hereafter regions)Regions) 
have gained full jurisdiction over WAL matters. The transposition of the EU WFD in Italy has prompted a number of legislative and institutional reforms, in which include the 2006 Environmental Code (EnC, in Italian: Testo Unico Ambiente, Legislative Decree 152/2006) [34].

According to the EnC, license holders are entitled to abstract a specified quantity of water from a particular source and for a specific purpose. The license award is conditional to conformity with minimum environmental flows. If the latter are not guaranteed, the regulator may impose revision or revocation of WAL. Temporary limitations may be enacted during prolonged periods of droughts. WAL holders are obliged to pay Water Concession Fees (WCF), a part of which, according to a recent regulation, is earmarked for implementing measures to improve and maintain a proper ecological status of water bodies [34]. The licenses are specified in absolute terms and are not transferable. Moreover, the temporal horizons for which the licenses are issued do not take into account the changing availability of water resources in the medium and long-term, as a result of climate change. Nor do they consider changes in the demand for water driven by population growth and economic development. Since human-induced climate change will likely result in a lower average annual water availability and a greater intra- and inter-annual variability [35], the National Climate Adaptation Strategy for the Po River Basin District (PRBD) has suggested revising the WAL regimes [36]. From our analysis of the PRBD case study, we propose recommendations on priorities for a national water abstraction reform, in line with international best practices on water abstraction reform [37-39].

\section{Water Management in the Po River Basin District}

The PRBD is the largest single river basin in Italy, spreading over $71,000 \mathrm{~km}^{2}(24 \%$ of the state territory) and is home to a growing human population of more than 17 million ( $+6 \%$ since 2001 , and expected to increase up to 18-21 million by 2050), most of whom live in small towns and cities with fewer than 25,000 inhabitants. The PRBD extends over several regions: Valle d'Aosta, Piedmont, Lombardy (all three almost entirely included in the basin), Emilia Romagna (about half of whose area is included in the basin), Veneto, Liguria and Tuscany (marginally included in the basin area). The Autonomous province of Trento is also partly covered by the PRBD. The river basin district hosts a dynamic economy that generates around 35\% of Italy's GDP, fuelled by some of the most vibrant industrial hubs in the proximity of the large urban centers of Milan, Turin, Brescia, Modena, Parma, Reggio nell'Emilia, Ferrara, Monza, Bergamo, Novara and Piacenza. The PRBD also offers services of strategic importance, including about 1200 hydroelectric power stations representing $41 \%$ of Italy's hydropower installed capacity, and 1180 thermo-electrical plants that produce around half of the country's thermoelectric energy. The PRBD also includes Italy's largest contiguous agricultural land area, nearly $21 \%$ of its total agricultural area, $21.5 \%$ of its utilized agricultural area, and almost $30 \%$ of its agricultural value added [17].

Total water abstractions (consumptive uses) from the Po river account for more than 20.5 billion $\mathrm{m}^{3}$ per annum (Table 1) most part of which (16.5 billion $\mathrm{m}^{3}$ ) is used in the agricultural sector, $2.5 \mathrm{billion}^{3}$ for drinking water and 1.5 billion $\mathrm{m}^{3}$ for industrial uses. Abstractions account for 14.5 billion $\mathrm{m}^{3}$ for surface waters and for 6 billion $\mathrm{m}^{3}$ for groundwater [40].

Table 1. Annual average water uses by sources. Legend (* energy production excluded) [41].

\begin{tabular}{|c|c|c|c|}
\hline Uses & Volume $\left(10^{6} \mathrm{~m}^{3} /\right.$ year $)$ & Surface Water (\%) & Groundwater (\%) \\
\hline Potable & 2500 & 20 & 80 \\
\hline Industrial * & 1537 & 20 & 80 \\
\hline Irrigation & 16,500 & 83 & 17 \\
\hline Total & 20,537 & 63 & 37 \\
\hline
\end{tabular}

Water use in the PRBD has increased over the last decades, and the volume of authorized WAL exceeds average water availability [42]. The problems become more pronounced during the irregular periods of drought spells. During the spring and the summer of 2003, a severe, persistent drought 
afflicted Southern Europe, including the PRBD. The Po River reached its absolute minimum at the closing section in Pontelagoscuro: $-6.99 \mathrm{~m}$ or $270 \mathrm{~m}^{3} / \mathrm{s}$ compared to an average of $1400 \mathrm{~m}^{3} / \mathrm{s}$. In 2006 and 2007, Northern Italy experienced another anomaly in terms of precipitation, and in 2007 river discharges were lower than in 2003. Since 2003, a State of (national) Emergency (SoE) under the law 224/1992 has been declared three times $(2003,2006$, and 2007) for a total duration of 21 months [43].

Water restrictions during droughts respect the priorities specified in the EnC [34], e.g., first the household water demand is satisfied, then the irrigation demand and lastly any other miscellaneous uses. The maintenance of minimum environmental flows was imposed in the late 1980s and later included in the EnC [34]. If shortages worsen to a SoE, the central government appoints a Commissioner Delegate with full powers to manage water bodies. With the aim of limiting welfare losses, the Commissioner Delegate may issue extraordinary water allocation rules that do not necessarily follow the EnC [34] protocol. The contemporary regulatory framework encourages voluntary agreements among users before the $\mathrm{SoE}$ is activated [34]. These agreements are managed in the context of the Drought Steering Committee (DSC).

The DSC was initiated and presided over by the Po River Basin Authority (PRBA) in May 2003, amidst a severe water crisis posing a threat to urban water supplies in the lower part of the district, and to irrigation throughout the whole district. The cooperative decision of the DSC was sanctioned by signing a Memorandum of Interest (MoI, in Italian: Protocollo d'Intesa), which stipulated the commitments of irrigators to reduce water withdrawal by $25 \%$ to $50 \%$, and hydropower operators to release more water from Alpine reservoirs and large regulated lakes. Moreover, the DSC sanctioned a close monitoring of evolving drought conditions. Since 2003, the DSC has been convened whenever persistent drought conditions have threatened to strain Italy's most important economic regions. The DSC also played an important advisory role during the SoE in the 2007 drought, institutionalized through the decree of the Commissioner Delegate for the management of the SoE [44].

Notwithstanding the increased frequency and intensity of droughts and the improved drought knowledge and response in the PRBD, these events are still predominantly managed by resorting to emergency instruments [45]. Proactive drought management instruments being used elsewhere, such as (incremental) water pricing [46], temporary trading of water rights [15,39,47], drought insurance [48] or even drought management plans [49], rely on flexible, consistent and sustainable WAL regimes that are currently non-existent in Italy. A WAL reform is imperative to define the main framework for planning and programming activities with a long-term water security perspective whose aim is to move away from an emergency approach to drought to a proactive and ongoing one.

\section{Water Abstraction Normative Regimes across the PRBD}

In 1933, R.D. 1775/1933 [32] established that nobody, not even a landowner, could withdraw water from natural water bodies without an authorized license. The only exception was water withdrawal for domestic use by landowners or tenants. Domestic use comprises water supply and sanitation, watering of gardens and orchards, and/or water used for livestock. This use is exempt from the obligation to declare withdrawal and hence payment of water concession fees. In both quantitative and qualitative terms, the impact of this exception is marginal. Under the current regimes the abstractions that are exempt from permits and fees are subject to limits that vary across the PRBD regions. In Piedmont, the flow rate must not exceed $2 \mathrm{~L} / \mathrm{s}$ and $5000 \mathrm{~m}^{3} /$ year, while in Lombardy it is limited to $1 \mathrm{~L} / \mathrm{s}$ and $1500 \mathrm{~m}^{3}$ /year. Veneto allows water withdrawal for domestic use in areas not served by aqueducts and limited to $0.1 \mathrm{~L} / \mathrm{s}$. In Emilia-Romagna and Valle d'Aosta, withdrawal limits are not specified.

An informal though widespread exception was made for groundwater use, which remained to a large extent outside of the WAL regime until 1994, when groundwater abstractions were converted to formal WALs after Galli Law 36/1994 [50], replaced in turn by the EnC in 2006. [34]. The GL [50] and the EnC [34] also oblige WAL owners to declare their existence and characteristics in order to make an overall census possible, although this objective has so far failed to be fully attained in the PRBD (see Section 5). 
The R.D. 1775/1933 [32] distinguished between Small Volume (SV) and Large Volume (LV) WALs (Table 2). For SV permits, R.D. 1775/1933 [32] entrusted WAL management to the Public Works Offices (PWO, in Italian: Ufficio Regionale del Genio Civile, is a regional peripheral authority on a provincial basis, which ensures all the functions relating to the execution of public works, while the LVs were controlled by the government. With Legislative Decree (in Italian: Decreto Legislativo, D.Lgs.) 112/1998, the WAL authorities were transferred to the regional governments. Where not otherwise specified, the provisions of the R.D. 1775/1933 [32] still apply.

Table 2. WAL differentiation by type of use (source: [32]).

\begin{tabular}{ccc}
\hline Uses & Small Volume Abstractions & Large Volume Abstractions \\
\hline Hydropower [HP] generation & $<3000 \mathrm{~kW}$ of installed capacity & $>3000 \mathrm{~kW}$ of installed capacity \\
Irrigation & $<1000 \mathrm{~L} / \mathrm{s}$ or $<500$ ha & $>1000 \mathrm{~L} / \mathrm{s}$ or $>500$ ha \\
Others & $<100 \mathrm{~L} / \mathrm{s}$ & $>100 \mathrm{~L} / \mathrm{s}$ \\
\hline
\end{tabular}

The five regions comprised regions included either entirely or substantially within the PRBD, have introduced to some extent different WAL regimes. Piedmont, Emilia-Romagna and Lombardy have adopted regulations or regional legislations throughout the period 2000-2006: first Emilia Romagna (Regional Regulation 41/2001; a Regional regulation, R.r., is not a law or primary source, but a secondary source that implements and integrates a law) [51], followed by Piedmont (R.r. 10R/2003) [52] and Lombardy (R.r. 02/2006) [53]. Valle d'Aosta, a region enjoying high administrative autonomy, applies a law which dates back to the 1950s (Regional Law 04/1956; in Italian: Legge regionale, L.r.) [54]. Veneto governs the WAL through sporadically updated regulations [55]. In the PRBD, regions issue licenses for LV abstractions and specify water concession fees for all types of uses. The regional authorities also have the faculty to enforce additional limits and obligations which the permit holders have to comply with, for safeguarding environmental integrity and quality and for contributing to the objectives of the regional Water Protection Plans (WPP, in Italian: Piano di tutela delle acque), which are revised every 6 years. On the other hand, WAL for SV abstractions are issued by lower administrative authorities, which are also in charge of making preliminary assessments of the compatibility of new and existing entitlements (both SV and LV). In Piedmont and Lombardy, the two latter roles are assumed by provincial authorities; in Veneto, by the PWO; and in Emilia-Romagna by Technical River Basin Services (TRBS), entities in charge of water management related issues and existing only in this region [56]. In Valle d'Aosta, given its small extent, the regional public water management office is responsible for both SV and LV abstraction licenses.

The administrative procedures for the concession of SV and LV WAL are rather similar across the PRBD regions (Figure 1). Permits are issued upon a satisfactory preliminary impact assessment. Preliminary assessments include the publication of the water concession application in the official regional bulletin (in Italian: Bollettino Ufficiale Regionale, BUR), an inspection (conferenza dei servizi) and, finally, the treatment of contingent oppositions and/or competing requests. Applicants are charged a fixed fee for the preliminary assessment, as opposed to the variable water abstraction fee detailed in Section 4. Preliminary assessments may also include the opinion of the PRBA, which unlike the regionally implemented Environmental Impact Assessments (EIA), is not binding. The EIA is based on the water concession flow rate and considers the environmental impacts to protected natural areas, such as Special Protection Areas or Special Areas of Conservation (SACs). Only if the EIA is positive is the water concession application accepted [34].

The only formal WAL that does not follow the administrative process described above is the "draw permit" (in Italian: attingimento), a temporary license related to contingent situations that allows the owner to withdraw surface water by means of mobile pumps. A draw license is granted for one year and can be renewed a maximum of 5 times. It may be revoked at any time on the basis of public interest, and without compensation for the license owner. In Piedmont, "draw license" also exist for the upper phreatic level. Piedmont and Lombardy have specific withdrawal limits for "draw license" $(60 \mathrm{~L} / \mathrm{s}$ 
and $40 \mathrm{~L} / \mathrm{s}$, respectively, and no more than 300,000 cubic metres per year each). Emilia-Romagna, Veneto and Valle d'Aosta refer to art.56 of R.D. 1775/1933 [32], which states that "draw licenses" are the responsibility of lower institutions (the Technical River Authority, the Public Works Office and the regional public water management office, respectively) as long as: (i) the water withdrawn is less than $100 \mathrm{~L} / \mathrm{s}$; (ii) damage to the river bank is avoided; and (iii) there is no modification of river conditions or negative impact on environmental uses.

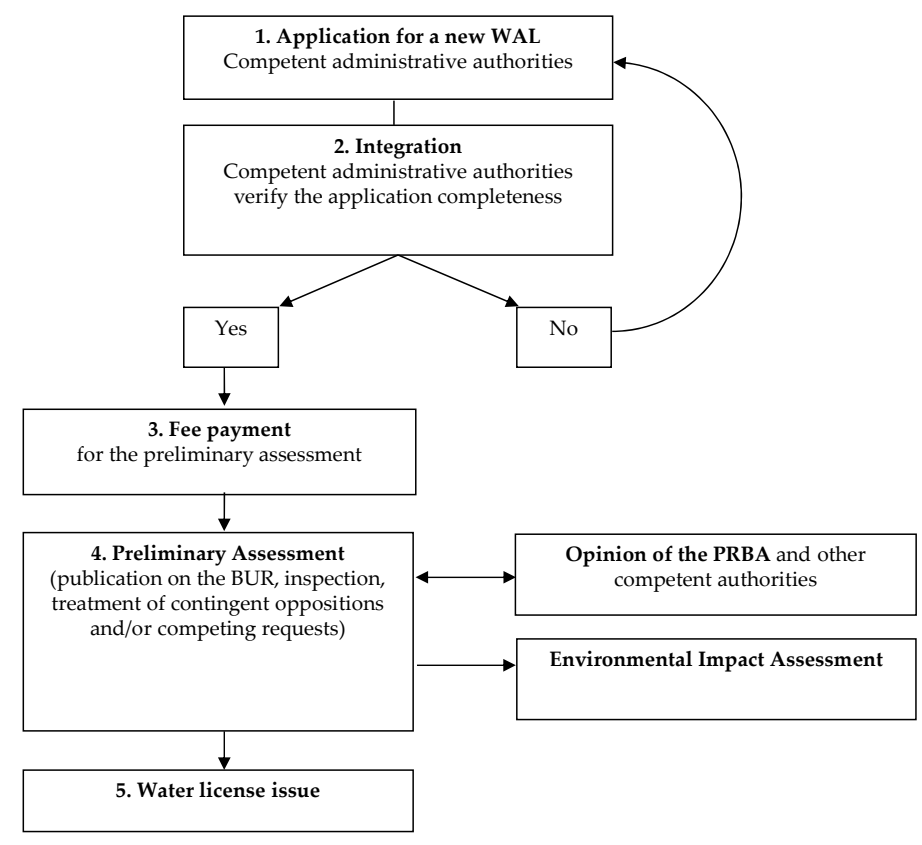

Figure 1. Administrative phases for LV and SV WAL across regions comprised in the PRBD. Source: Own elaboration.

The main water use categories are defined in the R.D. 1775/1933 [32] as civil, drinkable use; irrigation, energy production, industrial use; and health and sanitation use. The R.D. 1775/1933 [32] specifies a WAL duration of 40 years in the case of irrigation and 30 years for other uses, although regional laws may specify otherwise (Table 3).

Table 3. Terms of water uses for regions comprised regions included in the PRBD (source: own elaboration from [51-55]). Legend: * In the case of water rights allotted prior to 1956, Valle d'Aosta considers "no limitation" for Irrigation and Potable uses and 99 years for other uses.

\begin{tabular}{cccccc}
\hline Uses & Piedmont & Lombardy & Veneto & Emilia-Romagna & Valle d'Aosta * \\
\hline Irrigation & 40 & 40 & 40 & 40 & 40 \\
Potable & 30 & 30 & 30 & 30 & 30 \\
Civil & 30 & 30 & 30 & 30 & 30 \\
Industrial & 15 & 15 & 30 & 30 & 30 \\
Fish Farming & 30 & 40 & 30 & 40 & 30 \\
Energy & 30 & 30 & 30 & 40 & 30 \\
Sanitation & 30 & 30 & 30 & 40 & 30 \\
Zootecnic & 30 & 30 & 30 & 30 & 30 \\
Others & 30 & 30 & 30 & 30 & 30 \\
\hline
\end{tabular}

The application for the WAL renewal must be submitted before the license expires, after the promulgation of a new regulation that specifies requiring renewal, or in case a substantial variation of water withdrawal is intended. Piedmont and Lombardy specify tighter time constraints for WAL renewal: Piedmont's regulation states that the renewal application has to be submitted at least one 
year before the license expires, while Lombardy accepts the application for renewal only if submitted no later than six months before the license expires. Otherwise, the WAL can be revoked in which case a new WAL procedure is necessary (Figure 1). In all regions, WAL renewal may be declined for reasons connected to public interest [51-55].

An existing WAL can be revoked as a result of the following omissions or negligence: (i) the (intended) water use differs from the one granted; (ii) the user does not respect the conditions and requirements associated with the license; (iii) failure to pay the abstraction charge for two consecutive years; (iv) end of term of the concession; (v) sub-licensing to third parties (e.g., trading); (vi) structural allocative inefficiencies that cannot be addressed through temporary or permanent limitations in the WAL; and (vii) an inadequate environmental flow (EF) [51-55]. It is worth noting that environmental standards for water flows in Italy focus on minimum environmental flows [34] instead of the ecological flows necessary to guarantee a "a hydrological regime consistent with achieving WFD environmental objectives in natural surface water bodies" [57]. The legislations of Piedmont and Lombardy also consider the following cases: (viii) no abstraction for three consecutive years; and (ix) a failure to install flow rate metering devices, mandatory for new WAL [34].

Different norms and procedures across the PRBD have created a fragmented WAL regime, managed by regions and numerous lower administrative authorities. This situation is aggravated by persistent bureaucratic tangles, poor coordination among regions and insufficient supervision. Besides lacking a unifying set of norms, the PRBD also lacks a coordinating entity with powers extending beyond the PRBA's advisory role. Differing water abstraction fees and the largely uncontrolled overall WAL census reflect this substandard regulatory context.

\section{Water Concession Fees across the PRBD}

Water in Italy is charged through water fees and tariffs. Water tariffs are charges imposed on water storage, treatment and/or supply, and contribute to financial cost recovery of these services [58]. Water tariffs include charges levied by Land Reclamation and Irrigation Boards (in Italian: Consorzi di Bonifica e Irrigazione, public institutions that control land reclamation and about $90 \%$ of water distribution in agriculture), and prices domestic users pay for water supply and sanitation services. Water Concession Fees (WCFs) are charges paid by WAL holders typically according to the volume of water withdrawal permitted. WCFs were established by art.35 of R.D. 1775/1933 [32] and at present are fixed and levied by the regions (Bassanini D. Lgs 112/98 [59]). WCFs are detailed in Table 4 (prices are specified in harmonized units). WALs are typically specified in modules for all uses except for unmetered irrigation abstractions, where licenses are issued per ha, and hydropower, where licenses are issued per Kw. For all other uses, modules include the right to withdraw $100 \mathrm{~L} / \mathrm{s}$, except for industrial uses, where modules include a flow of $3 \mathrm{~L} / \mathrm{s}$ in all regions but Lombardy (again $100 \mathrm{~L} / \mathrm{s}$ ) and Piedmont (1 L/s).

Where water is abstracted for different uses by the same WAL holder and the volumes abstracted cannot be split to account for different uses, the WCF corresponds to the water use for which the highest fee is due. If metering is available, the WCF is proportional to existing uses. In the particular case where a single water abstraction combines irrigation and hydroelectricity uses (a traditional practice in the PRBD known as molinare), the WCF corresponds to the use with the highest fee.

On top of the regular WCF, hydropower operators pay an additional fee to local authorities for grants and exploitation of public waters for producing electricity. There exist two supplementary fees: i) a Supplementary Fee for Riparian Authorities (in Italian: Sovracanone Enti Rivieraschi) is paid by plants with an installed capacity above $220 \mathrm{~kW}$ and amounts to $5.72 € / \mathrm{kW}$ in case the capacity is below $3000 \mathrm{Kw}$, and $7.35 € / \mathrm{kW}$; otherwise, the revenues thus raised are divided among the regions, provinces and riverain municipalities on a predetermined basis. A Supplementary Fee for Mountain Basins (in Italian: Sovracanone per bacini imbriferi Montani) is collected by municipalities and paid by operators located in mountainous areas with an installed capacity greater than $220 \mathrm{~kW}$, amounting to $22.88 € / \mathrm{kW}$ in case the capacity is below $3000 \mathrm{Kw}$, and otherwise $30.40 € / \mathrm{kW}$. 
Table 4. Water abstraction fees (as in 2014) for the major water uses across the PRBD regions. Source: own elaboration from [60-64]. Legend: ${ }^{1}$ abstraction with return; ${ }^{2}$ abstraction $>3000 \mathrm{~L} / \mathrm{s} ;{ }^{3}$ large volume abstraction $(>3000 \mathrm{~kW}) ;^{4}$ small volume abstraction, installed capacity $<220 \mathrm{~kW} ;{ }^{5}$ small volume abstraction, $220 \mathrm{~kW}<$ installed capacity $<3000 \mathrm{~kW} ;{ }^{6}$ surface water; ${ }^{7}$ groundwater.

\begin{tabular}{|c|c|c|c|c|c|c|}
\hline Use & Unit & Lombardy & Piedmont & Emilia-Romagna & Veneto & Valle d'Aosta \\
\hline Potable & $€ / L / s$ & 22.51 & $22 . .22$ & 20.43 & 43.06 & 20.49 \\
\hline \multirow[t]{2}{*}{ Irrigation } & Metered, $€ / \mathrm{L} / \mathrm{s}$ & $0.53 ; 0.26^{1}$ & 0.53 & 0.48 & $1.01 ; 0.51^{1}$ & 0.48 \\
\hline & Unmetered, €/ha & 0.53 & 1.16 & 0.44 & 0.919 & 0.45 \\
\hline Industrial & $€ / L / s$ & $\begin{array}{l}165.30 \\
333.22^{2}\end{array}$ & 166.74 & 142.41 & 300.42 & $142.97 ; 71.49^{1}$ \\
\hline Hydropower & $€ / \mathrm{kW}$ & $15.35 ; 30.91^{3}$ & 28.24 & 13.93 & 29.38 & $\begin{array}{c}18.54^{4} ; 22.66^{5} \\
25.76^{3}\end{array}$ \\
\hline Civil & $€ / L / s$ & 11.25 & 11.11 & 10.33 & 21.53 & 10.25 \\
\hline Fish Farming & $€ / L / s$ & 3.75 & 3.74 & 3.41 & $3.76^{6} ; 7.18^{7}$ & 3.42 \\
\hline Sanitary & $€ / L / s$ & 11.25 & 11.11 & 10.33 & 21.53 & 10.25 \\
\hline Zootecnic & $€ / L / s$ & 11.25 & 56.72 & 10.33 & 21.53 & 10.25 \\
\hline
\end{tabular}

The rationale behind the WCF is that of charging water users the costs stemming from the private use of a public good (art.35 of R.D. 1775/1933), making this instrument the apparent choice for the recovery of resource and environmental costs of water use [1]. Ministerial Decree 39/2015 developed guidelines for defining resource and environmental costs and identified WCFs as an adequate instrument for reducing (if water is conserved) or recovering them. Resource costs are defined as the best use foregone (e.g., opportunity cost); environmental costs are the expenses, interventions or commitments necessary to restore a good ecological status of water bodies or to limit or contain damage stemming from a specific use. Environmental and resource costs should account for both the quantity and quality of water and for seasonal variations [65]. In reality, though, there is insufficient data on the total revenues annually collected by regions through WCFs, and these are generally considered insufficient for the purpose of recovering environmental and opportunity costs [66]. This is aggravated by the WCFs actually declining charges, since the applied projected inflation rate used for updating WCFs falls far below the real inflation rate (initially introduced under the Galli Law 36/1994 [50], then replaced by each regional WAL). In addition, WCFs are calculated on the basis of the potential and not the actual volume of water withdrawn, a method that removes incentives for water saving/conservation. Metering is a prerequisite for any incentive charging policy [2] and its adoption has recently increased in the regions included in the PRBD in the wake of the EnC [34], which made it compulsory to install metering devices for new WALs [34]. However, the adoption of metering devices in agriculture is still insufficient for implementing volumetric charges that address region-wide or basin-wide quantitative challenges [67].

There are also substantial equity issues related to WAL charging. WCF rates appear to be guided more by the user's ability to pay than by the activity's environmental and resource costs. For example in Lombardy, where droughts are becoming an increasingly vital issue, industrial uses represent $5 \%$ of the WAL and $63 \%$ of the collected fees. WCFs also vary substantially across regions, a situation that cannot be explained solely by differing resource and environmental costs, but also by other economic and policy factors that affect equity among otherwise similar water uses across the basin.

The revenue raised through WCFs in the PRBD is not specifically addressed towards protecting and/or restoring vulnerable water ecosystems, -in contrast to existing regulations (article 119, comma 2-a of the EnC [34]). WCFs are typically incorporated the gross regional budgets instead of remaining a separate line item related to water management. An exception is the region of Piedmont, which allocates part of its WCF funds to specific (though mostly unrelated to water management) line items, namely, a fund for the economic support of mountain communities ( $30 \%$ of the revenues) and water monitoring (5\%) in the context of the WPP. 


\section{WAL Census}

Physical water balances (or budgets) are essential for a quantitative management of water resources [2,57]. Similarly, a census of abstraction licenses is critically important for understanding water demands within a river basin. Information on the number and characteristics of WALs in Italy is not publicly accessible. For our analysis we have collected disaggregated data from various regional and sub-regional authorities, except for Emilia-Romagna, for which we have only obtained data aggregated at the provincial level. The records are highly heterogeneous. We have reviewed and processed the data and compiled a database that is nearly equivalent to a census. It includes information concerning 70,000 abstraction licenses and contains detailed technical and administrative information on each of them. Table 5 summarizes water uses in the PRBD. The heterogeneous units of measurement were converted to $\mathrm{m}^{3} / \mathrm{s}$ to make them comparable.

Table 5. WAL Census (source: own elaboration based on WAL data collected from regional authorities [68-72]).

\begin{tabular}{|c|c|c|c|c|c|}
\hline \multirow[b]{2}{*}{ Uses } & \multirow[b]{2}{*}{$\begin{array}{c}\text { NO. of } \\
\text { Abstractions }\end{array}$} & \multicolumn{2}{|c|}{ Average Water Use } & \multicolumn{2}{|c|}{ Maximum Water Use } \\
\hline & & $\begin{array}{l}\% \text { of Abstractions with } \\
\text { Available Information }\end{array}$ & Total $\left(\mathrm{m}^{3} / \mathrm{s}\right)$ & $\begin{array}{l}\text { \% of Abstractions } \\
\text { with Available } \\
\text { Information }\end{array}$ & Total $\left(\mathrm{m}^{3} / \mathrm{s}\right)$ \\
\hline Irrigation & 21,909 & $57.8 \%$ & 1653.6 & $17.2 \%$ & 1690.3 \\
\hline Potable & 8180 & $75.5 \%$ & 342.0 & $19.5 \%$ & 79.0 \\
\hline Industrial & 6864 & $76.7 \%$ & 411.9 & $22.0 \%$ & 49.5 \\
\hline Energy & 3430 & $85.4 \%$ & 6466.1 & $49.3 \%$ & 7531.5 \\
\hline Sanitation & 8639 & $82.6 \%$ & 13.9 & $8.4 \%$ & 3.6 \\
\hline Zootecnic & 5798 & $83.4 \%$ & 6.6 & $10.8 \%$ & 113.9 \\
\hline Other uses & 6773 & $56.2 \%$ & 24.9 & $26.8 \%$ & 22.1 \\
\hline Unspecified use & 10,190 & $0.3 \%$ & 24.1 & $0.3 \%$ & 34.9 \\
\hline Total & 72,489 & $59.8 \%$ & 8975.1 & $16.4 \%$ & 9535.4 \\
\hline
\end{tabular}

The recorded characteristics typically include geographical coordinates of the withdrawal point, water source/body, type of permitted water use, status of license (active, expired or under review) and implied conditions, and time limit. The license is specified in absolute terms, either as average or (less frequently) maximum volume of flow that can be withdrawn. Piedmont, Lombardy and Valle d'Aosta specify both values. Where the maximum volume of flow that can be withdrawn is not specified, users have the opportunity to increase abstractions during drought events, precisely when it is a most valuable resource, and reduce its use during water abundant years so as to comply with average water use standards. Only some regions record return flows (Piedmont and Valle d'Aosta).

Withdrawal periods may be limited to irrigation seasons (April-September) but typically extend over the whole year. Some licenses, especially in the case of irrigation, do not define the abstraction volume. Therefore our analysis is partly incomplete. As drought spells are becoming more frequent and intense, gaps in the WAL Census may become a critical issue [37]. In an effort to improve coordination among the different authorities in charge of managing WAL within the boundaries of the PRBD, the Piedmont region recently created an online WAL database called the Water Resources Information System (in Italian: Servizio d'Informazione delle Risorse Idriche (SIRI)) [73].

\section{Discussion and Conclusions}

A more flexible WAL regime in Italy is to be recommended, on account of the observed and expected decline in water availability, amplified climate variability [36], population growth and economic development, and as a means of regulating minimum environmental flows. In this article we look at the case of the of the PRBD, the largest and economically most important river basin district in Italy. We assess the deficiencies of the current WAL regime and we argue these may compromise both the integrity of riverine and water dependent ecosystems and the economic uses of water. The lack of 
a central WAL register delays and in some cases impedes an environmental impact assessment for issuing new licenses or renewing existing ones, and does not allow prioritizing applications according to their full economic value. It also does not allow taking the edge off the rising conflicts among the different water users during the times of temporary water shortages. The water pricing in place does not reflect the cost of water conveyance and use, and does not encourage efficient water use. The regime is too rigid to permit formal or informal agreements among users, let alone the transfer (temporary or permanent) of existing permits. Finally, the current regime hinders the performance of bottom-up conflict resolution mechanisms such as the Drought Steering Committee. A reform should be inspired by international experience [13-16,74], while taking into account specific legal, institutional, economic and political conditions, in Italy in general and in the PRBD in particular. Based on our review we formulate the following recommendations that contribute to a greater water security in the district:

First, the WAL regime should specify the entitlements as shares of harvestable water resources and entitle shareholders to periodic allocations of water volumes that can be withdrawn for approved, site-specific purposes. Environmental outcomes should be managed by establishing minimum requirements in plans and perhaps by assigning shares to environmental trusts or their equivalents.

Second, transparency in governance and allocation arrangements should be granted by means of pre-established rules and procedures out stipulated in the river basin district plans. These rules should be reviewed periodically, say every ten years, and should clarify when, how and how much water will be allocated to each share-holder, and under what conditions unused allocations can be carried forward from one year to the next.

Third, the entitlements should check on the rate of return flow, so as to avoid harming the entitlements of downstream users.

Fourth, a single register of all water entitlements across the entire river basin district should be introduced and perhaps made publicly accessible.

Fifth, the river basin (district) authority should play a major role in controlling the environmental compatibility of the intended withdrawals, particularly for large volume abstractions. The WAL regime should respect the interconnection of and interaction between embedded ground/surface water systems, and between land (management) and the water cycle (run-off, infiltration and evapotranspiration). This, together with the register of entitlements, will favor the development of environmental-economic accounts [34].

Sixth, in the absence of or during the transition to genuine WAL trading schemes the water concession fees should be designed as incentives for (more) efficient water use and allocation [58]. The revenues collected by regions should cover operational costs of the WAL regime, including the monitoring, control, surveillance and enforcement costs. It is preferable to design the WCF as consisting of a fixed component and a variable component. Smart water meters should be installed for all abstraction licenses; not only for the new ones, but progressively for all existing abstraction permits.

Seventh, the potential efficiency achieved by making water entitlements transferable should be analyzed in depth. Properly designed water markets can both reveal the full economic value of water and facilitate its shift to highest value uses. The ample existing infrastructure favors physical water transfers and trading with licenses. However, in light of the manifested public opposition [75], it is not realistic to introduce a genuine trading scheme any time soon. If tradable permits are developed eventually, statutory plans need to anticipate potential market failures and define rules for determining whose shares and allocations can be traded.

Eighth, the length for which the WAL should be issued depends on whether or not introducing tradable permit schemes is envisaged in the long term. If there is an expectation of permission to trade with WAL in the future, then licenses should be released in perpetuity or, at least, with no time limits, in order to favor long-term investments and innovation. If not, licenses should be granted for durations that permit regular "back-end" adaptation to changing patterns of precipitation and river 
flow. Any changes in license durations should be managed by rules and procedures set forth in river basin district plans and/or regional water conservation plans.

These non-exhaustive principles and the complementary public debate have the potential to overcome the institutional "maze" which characterizes the current WAL regime. Our recommendations respond to allocation inefficiencies we have observed in the PRBD. They may have omitted relevant aspects that such a reform needs to tackle elsewhere. Still, our recommendations draw on EU and Italian policy guidelines [1,2,34,57], and build upon international standards [16] and experiences. We believe that this analysis offers helpful insights for water allocation reform elsewhere in Italy and in Europe, not least in river basin districts with similar characteristics. The new WAL regime should be robust yet flexible, and reliable yet sustainable. It should balance robustness at the user level with flexibility at the system level, and address trade-offs between efficiency and equity, while guaranteeing environmental sustainability and hydrological integrity.

It is clear that the proposed reform will not be unproblematic. While many recognize that the current license regime fails to allocate water sustainably and efficiently [76,77], there is a considerable divergence of opinions on how the regime should be reorganized $[78,79]$. It is not conceivable to design, let alone to implement, a reform of a such magnitude without extensive public consultation and scrutiny. Interest groups, even if small, are well-organized and influential, and thus are capable of hampering public policy dialogue and impeding transformative change [80]. A practicable way forward for Italy is a stepwise transition to a (more) resource efficient economy [81,82], an integral part of which is a modern water allocation regime that is consistent with the principles we have outlined.

This research highlights areas in which a concerted policy response is warranted. Although at present there is no plan or intention to embark in a similar policy debate, our contribution has shown that the topic of WAL is important and should be handled with a high priority. Future research should explore how to inform, open and strengthen the policy dialogue that could eventually lead to a new WAL regime and a greater water security in the PRBD and elsewhere in Italy. The analysis and recommendations above represent a first attempt which may help in this regard.

Acknowledgments: This research has received funding from the European Union under grant agreements No. 308438 (ENHANCE-Enhancing risk management partnerships for catastrophic natural disasters in Europe) and No. SEE/C/0001/2.2/X (ORIENTGATE-A structured network for integration of climate knowledge into policy and territorial planning). We are grateful to Carlo Enrico Cassani (Region of Lombardy), Paolo Mancin and Giuseppe Alampi (Region of Piedmont), Ivan Marguerettaz (Region of Valle d'Aosta) and Antonio de Fazio (Region of Veneto) for their help in providing the data that went into our analysis. Finally, we would like to thank Mike Young and two anonymous reviewers for their valuable comments and suggestions.

Author Contributions: Silvia Santato and Jaroslav Mysiak designed the work. Silvia Santato developed the database. Silvia Santato, Jaroslav Mysiak and Carlos Dionisio Pérez-Blanco analyzed the data. Silvia Santato, Jaroslav Mysiak and Carlos Dionisio Pérez-Blanco wrote the paper.

Conflicts of Interest: The authors declare no conflict of interest.

\section{References}

1. European Commission. Water Framework Directive 2000/60/EC; European Commission: Brussels, Belgium, 2000.

2. European Commission. A Blueprint to Safeguard Europe's Water Resources. Communication from the Commission to the European Parliament, the Council, the European Economic and Social Committee and the Committee of the Regions. COM(2012) 673 Final; European Commission: Brussels, Belgium, 2012.

3. European Commission. Communication from the Commission to the European Parliament, the Council, the European Economic and Social Committee and the Committee of the Regions: Reinforcing Economic Policy Coordination. $\operatorname{COM(2010)} 250$ Final; European Commission: Brussels, Belgium, 2010.

4. European Commission. Communication from the Commission to the European Parliament, the Council, the European Economic and Social Committee and the Committee of the Regions An EU Strategy on Adaptation to Climate COM(2013) 216 Final Change; European Commission: Brussels, Belgium, 2013. 
5. Organisation for Economic Co-operation and Development. Water Security for Better Lives; Organisation for Economic Co-operation and Development: Paris, France, 2013.

6. European Commission. Communication from the Commission to the European Parliament and the Council Addressing the Challenge of Water Scarcity and Droughts in the European Union. COM(2007) 414 Final; European Commission: Brussels, Belgium, 2007.

7. Strosser, P.; Dworak, T.; Delvaux, P.G.A.; Berglund, M.; Schmidt, G.; Mysiak, J.; Kossida, M.; Iacovides, I.; Ashton, V. Gap Analysis of the Water Scarcity and Droughts Policy in the EU; European Commisison Directorate General Environment, Final Report Tender ENV.D.1/SER/2010/0049; European Commission: Brussels, Belgium, 2012.

8. European Parliament. Report on Towards a Stronger European Disaster Response: The Role of Civil Protection and Humanitarian Assistance; (2011/2023 INI)) A7-0283/2011; European Parliament: Bruxelles, Belgium, 2011.

9. European Environment Agency. Water Resources in Europe in the Context of Vulnerability; Report 12/2012; European Environment Agency: Copenhagen, Denmark, 2012.

10. European Environment Agency. European Waters-Current Status and Future Challenges; Report 9/2012; European Environment Agency: Copenhagen, Denmark, 2012.

11. Ciscar, J.-C.; Feyen, L.; Soria, A.; Lavalle, C.; Raes, F.; Perry, M.; Nemry, F.; Demirel, H.; Rozsai, M.; Dosio, A.; et al. Climate Impacts in Europe-The JRC PESETA II Project, EUR-Scientific and Technical Research; Joint Research Centre: Ispra, Italy, 2014.

12. United Nations. The United Nations World Water Development Report 2014; United Nations: New York, NY, USA, 2014.

13. Mysiak, J.; Vollaro, M.; Gómez, C.M.; Andersen, M.S.; Defrance, P.; Delvaux, P.A.G.; Green, C.; Dworak, T.; Davide, M.; Delacámara, G.; et al. EPI-WATER Synthesis Report, Report of the EPI-WATER Project; EPI-WATER: Venice, Italy, 2013.

14. Young, M. Environmental Effectiveness and Economic Efficiency of Water Use in Agriculture. In OECD Studies on Water; Organisation for Economic Co-operation and Development: Paris, France, 2010; pp. 1-33.

15. Young, M. The Role of the Unbundling Water Rights in Australia's Southern Connected Murray Darling Basin, Report of the EPI-WATER Project; EPI-WATER: Venice, Italy, 2011.

16. Organisation for Economic Co-operation and Development. Water Resources Allocation: Sharing Risks and Opportunities; Organisation for Economic Co-operation and Development: Paris, France, 2015.

17. Mysiak, J.; Carrera, L.; Massarutto, A. Servizio idrico e l'approvvigionamento di acqua nel contesto dei cambiamenti climatici. In Qualità Dell'ambiente Urbano, IX Rapporto, Focus su Acque e Ambiente Urbano; ISPRA; ISPRA-Istituto Superiore per la Protezione e la Ricerca Ambientale: Rome, Italy, 2013; pp. 113-120. (In Italian)

18. Parliament of the United Kingdom. Water Resources Act 1963. Available online: http://www.legislation. gov.uk/ukpga/1963/38/contents (accessed on 9 October 2015).

19. Environmental Agency and OFWAT. The Case for Change-Reforming Water Abstraction in England; Environmental Agency and OFWAT: Rotherham, UK, 2011.

20. Environmental Agency. Abstraction and Flow Problem-Significant Water Management Issues; Environmental Agency: Rotherham, UK, 2013; pp. 1-13.

21. Parliament of the United Kingdom. Water Resources Act 1991. Available on line: http://www.legislation. gov.uk/ukpga/1991/57/contents (accessed on 9 October 2015).

22. Environmental Agency. Abstraction Charging Scheme; Environmental Agency: Rotherham, UK, 2014.

23. Cave, M. Independent Review of Competition and Innovation in Water Markets: Final Report; Defra: London, UK, 2009.

24. Department for Environment, Food and Rural Affairs. The Natural Choice: Securing the Value of Nature; Defra: London, UK, 2011.

25. Department for Environment, Food and Rural Affairs. Water for Life. Market Reform Proposals; Defra: London, UK, 2011.

26. Department for Environment, Food and Rural Affairs. Water for Life; Defra: London, UK, 2011.

27. Boletín Oficial del Estado. Ley 29/1985, de 2 de Agosto, de Aguas; BOE: Madrid, Spain, 1985; Volume 189. (In Spanish)

28. Boletín Oficial del Estado. Ley 46/1999 de 13 de Diciembre, de Modificación de la Ley 29/1985, de 2 de Agosto, de Aguas; BOE: Madrid, Spain, 1999. (In Spanish) 
29. Boletín Oficial del Estado. Real Decreto-Ley 15/2005, de 16 de Diciembre, de Medidas Urgentes Para la Regulación de Las Transacciones de Derechos al Aprovechamiento de Agua (Vigente hasta el 30 de Noviembre de 2009); BOE: Madrid, Spain, 2005; Volume 15. (In Spanish)

30. Boletín Oficial del Estado. Real Decreto-Ley 606/2003, de 23 de Mayo, por el que se Modifica el Real Decreto 849/1986, de 11 de Abril, por el que se Aprueba el Reglamento del Dominio Público Hidráulico, que Desarrolla los Títulos Preliminar, I, IV, V, VI y VIII de la Ley 29/1985, de; BOE: Madrid, Spain, 2003; Volume 606. (In Spanish)

31. Organisation for Economic Co-operation and Development. OECD Environmental Performance Reviews: Italy 2013. Available online: http:/ /dx.doi.org/10.1787/9789264186378-en (accessed on 10 September 2015).

32. Ministero dell'Ambiente e Della Tutela del Territorio e del Mare. Regio Decreto 11 Dicembre 1933, n. 1775-Testo Unico Delle Disposizioni di Legge Sulle Acque e Impianti Elettrici (G.U. 8 Gennaio 1934, n. 5). Available online: http://www.minambiente.it/sites/default/files/R.D._11-12-1933_n._1775.pdf (accessed on 9 October 2015). (In Italian).

33. Goria, A.; Lugaresi, N. The Evolution of the National Water Regime in Italy; Istituto per la Ricerca Sociale: Bologna, Italy, 2002.

34. Parliament of Italy. Testo Unico Ambientale 152/2006. Available online: http:/ /www.camera.it/parlam/ leggi/deleghe/06152dl2.htm (accessed on 9 October 2015). (In Italian).

35. Coppola, E.; Giorgi, F. An assessment of temperature and precipitation change projections over Italy from recent global and regional climate model simulations. Int. J. Climatol. 2010, 30, 11-32. [CrossRef]

36. Ministero dell'Ambiente e della Tutela del Territorio e del Mare. Rapporto Sullo Stato Delle Conoscenze Scientifiche su Impatti, Vulnerabilità ed Adattamento ai Cambiamenti Climati ci in Italia. Available online: http:/ / www.minambiente.it/sites/default/files/archivio/allegati/clima/strategia_adattamentoCC.pdf (accessed on 9 October 2015). (In Italian).

37. Carrera, L.; Mysiak, J.; Crimi, J. Droughts in Northern Italy: Taken by Surprise, Again. Available online: http:/ / www.feem.it/getpage.aspx?id=5594 (accessed on 10 September 2015).

38. Young, M. Towards a Generic Framework for the Abstraction and Utilisation of Water in England and Wales; Visiting Fellowship Report 2012; UCL Environment Institute: London, UK, 2012.

39. Rey, L.; Calatrava, J.; Garrido, A. Water Market Scenarios for Spain, Deliverable WP2 Water Cap and Trade; IWRM-NET: Madrid, Spain, 2011.

40. EPI-WATER. WP3 EX-POST Case Studies: Payment by the Drop: The Move to Water Metering in England and Wales; EPI-WATER: Venice, Italy, 2011.

41. Massarutto, A.; Musolino, D. Po River Basin, Italy Drought management in a wide, densely populated and highly developed area. Available online: http://www.eu-drought.org/media/default.aspx/emma/ org/10815140/CS+Po_IT_flyer_1.pdf (accessed on 10 September 2015).

42. Autorità di Bacino del Fiume Po. Sintesi Dell'analisi Economica Sull'utilizzo Idrico. Elaborato 6, Piano di Gestione; Autorità di Bacino del Fiume Po: Parma, Italy, 2010.

43. Mysiak, J.; Carrera, L.; Massarutto, A. Sicurezza idrica nel contesto dei cambiamenti climatici. In Qualità Dell'ambiente Urbano, IX Rapporto, Focus su Acque e Ambiente Urbano; L'istituto Superiore per la protezione e la ricerca ambientale (ISPRA): Roma, Italy, 2013; pp. 113-120.

44. Calliari, E. Ordinary and Extraordinary Tools for Managing Drought. The 2003 and 2006/2007 Events in the Po River Basin; Bocconi University: Milan, Italy, 2011.

45. Civita, M.V. Ground Water in the Southern Member States of the European Union: an Assessment of Current Knowledge and Future Prospects-Country Report for Italy; European Academies Science Advisory Council: Halle, Germany, 2011.

46. California State Legislature. California Water Code; California State Legislature: Sacramento, CA, USA, 2013.

47. Hanak, E.; Lund, J.; Dinar, A.; Gray, B.; Howitt, R.; Mount, J.; Moyle, P.; Thompson, B. Managing California's Water: From Conflict to Reconciliation; Public Policy Institute of California: San Francisco, CA, USA, 2011.

48. Pérez-Blanco, C.D.; Gómez, C.M. Insuring water: A practical risk management option in water-scarce and drought-prone regions? Water Policy 2014, 16, 244-263. [CrossRef]

49. European Commission. Drought Management Plan Report; Report 23; European Commission: Brussels, Belgium, 2008.

50. Parlamento Italiano. Legge Galli N.36, 1994 Disposizioni in Materia di Risorse Idriche. Available online: http://www.gazzettaufficiale.it/eli/id/1994/01/19/094G0049/sg (accessed on 9 October 2015). (In Italian). 
51. Regione Emilia-Romagna. Regolamento per le Disciplina del Procedimento di Concessione di Acqua Pubblica. Regolamento Regionale 20 Novembre 2001, n. 41; Regione Emilia-Romagna: Bologna, Italy, 2001; pp. 1-17.

52. Regione Piemonte. Regolamento Regionale 29 Luglio 2003, n.10/R, Disciplina dei Procedimenti di Concessione di Derivazione di Acqua Pubblica; Regione Piemonte: Torino, Italy, 2003; pp. 1-42.

53. Regione Lombardia. Regolamento Regionale 24 Marzo 2006, n. 2, Disciplina Dell'uso Delle Acque Superficiali e Sotterranee, Dell'utilizzo Delle Acque a uso Domestico, del Risparmio Idrico e del Riutilizzo Dell'acqua; Regione Lombardia: Milano, Italy, 2006.

54. Regione Autonoma della Valle d'Aosta. Legge Regionale 8 Novembre 1956, n. 4. Norme Procedurali per la Utilizzazione Delle Acque Pubbliche in Valle d'Aosta; Regione Autonoma della Valle d'Aosta: Aosta, Italy, 1956.

55. Regione Veneto. Deliberazione Della Giunta Regionale n. 1664 del 22 Giugno 2010: Disposizioni per la Presentazione e la Pubblicazione Delle Domande di Concessione di Derivazione D'acqua; Regione Veneto: Venezia, Italy, 2010.

56. Regione Emilia-Romagna. Deliberazione Della Giunta Regionale n. 1260 del 22 Luglio 2002: Rivisitazione Dell'assetto Delle Funzioni in Materia di Difesa del Suolo, dei Bacini Idrografici e Della Costa; Regione Emilia-Romagna: Bologna, Italy, 2002. (In Italian)

57. European Commission. Ecological Flows in the Implementation of the Water Framework Directive, Guidance Document No. 21; Technical Report-2015-086; European Commission: Brussels, Belgium, 2015.

58. European Environment Agency. Assessment of Cost Recovery through Water Pricing; No. 16; European Environment Agency: Copenhagen, Denmark, 2013.

59. Parlamento Italiano. Decreto Legislativo 31 Marzo 1998, n. 112 Conferimento di Funzioni e Compiti Amministrativi Dello Stato Alle Regioni ed Agli Enti Locali, in Attuazione del Capo I Della Legge 15 Marzo 1997, n. 59, Available online: http://www.parlamento.it/parlam/leggi/deleghe/98112dl.htm (accessed on 9 October 2015). (In Italian).

60. Regione Lombardia. Canoni Acque Pubbliche 2016, Available online: http://www.reti.regione.lombardia.it/ cs/Satellite?c=Redazionale_P\&childpagename=DG_Reti/Detail\&cid=1213550944051\&pagename=DG_ RSSWrapper (accessed on 15 September 2015). (In Italian).

61. Regione Piemonte. Canoni Per Uso Delle Acque Pubbliche, Available online: http://www.regione.piemonte.it/ ambiente/acqua/atti_doc_adempimenti.htm (accessed on 15 September 2015). (In Italian).

62. Regione Emilia-Romagna. Canoni Acque Pubbliche, Available online: http://ambiente.regione.emiliaromagna.it/suolo-bacino/servizi/canoni/canoni-acque-pubbliche (accessed on 15 September 2015) . (In Italian).

63. Regione Autonoma della Valle d'Aosta. Ufficio Gestione Demanio Idrico:Canoni Acque Pubbliche; Regione Autonoma della Valle d'Aosta: Aosta, Italy, 2015. (In Italian)

64. Regione Veneto. Ufficio regionale del Genio Civile: Canoni Acque Pubbliche; Regione Veneto: Venezia, Italy, 2015. (In Italian)

65. Ministero dell'Ambiente e della tutela del territorio e del mare. Decreto Ministeriale 24 Febbraio $2015, n$. 39-Regolamento Recante i Criteri Per la Definizione Dei Costi Ambientali e Della Risorsa Per i Vari Settori D'impiego Dell'acqua; Ministero dell'Ambiente e della tutela del territorio e del mare: Rome, Italy, 2015. (In Italian)

66. Autorità di Bacino fiume Po. Piano di Gestione del Distretto Idrografico del Fiume Po. Studio di Fattibilità Analisi Economica Utilizzo Idrico Scala del Bacino del Po-Attività Integrative; Autorità di Bacino fiume Po: Parma, Italy, 2010. (In Italian)

67. Istituto Nazionale di Economia Agraria. Atlante Nazionale Dell'irrigazione, a Cura di Raffaella Zucaro; INEA: Roma, Italy, 2011. (In Italian)

68. Regione Autonoma della Valle d'Aosta. Ufficio Gestione Demanio Idrico: Database Delle Concessioni di Derivazione Dell'acqua Pubblica; Regione Autonoma della Valle d'Aosta: Aosta, Italy, 2015.

69. Regione Lombardia. Unità Organizzativa Risorse Idriche: Database Delle Concessioni di Derivazione Dell'acqua Pubblica; Regione Lombardia: Milano, Italy, 2015. (In Italian)

70. Regione Piemonte. Settore Tutela Quantitativa e Qualitativa Delle Acque: Database Delle Concessioni di Derivazione Dell'acqua Pubblica; Regione Piemonte: Torino, Italy, 2015. (In Italian)

71. Regione Veneto. Ufficio regionale del Genio Civile della Provincia di Rovigo: Database delle concessioni di derivazione dell'acqua pubblica; Regione Veneto: Venezia, Italy, 2015. (In Italian)

72. Regione Emilia Romagna. Piano di Tutela delle Acque (PTA); Regione Emilia Romagna: Bologna, Italy 2005, 2015. (In Italian) 
73. Regione Piemonte. SI Risorse Idriche (SIRI)/SI Bonifica e Irrigazione (SIBI). Available online: http://www.sistemapiemonte.it/cms/pa/ambiente/servizi/202-siri-si-risorse-idriche-sibi-si-bonifica-eirrigazione. (accessed on 15 September 2015). (In Italian).

74. European Environment Agency. Water Resources in Europe in the Context of Vulnerability-EEA 2012 State of Water Assessment; European Environment Agency: Copenhagen, Denmark, 2012.

75. Servizio Studi-Dipartimento ambiente della Camera dei Deputati. Il Servizio Idrico Integrato e il Referendum Abrogativo del 12-13 Giugno 2011. Available online: http://documenti.camera.it/leg16/dossier/Testi/ AM0232.htm (accessed on 15 September 2015). (In Italian).

76. Crase, L.; O'Keefe, S.; Dollery, B. Talk is cheap, or is it? The cost of consulting about uncertain reallocation of water in the Murray-Darling Basin, Australia. Ecol. Econ. 2013, 88, 206-213. [CrossRef]

77. Young, M. Trading Into Trouble? Lessons from Australia's Mistakes in Water Policy Reform Sequencing. In Water Markets for the 21st Century; Springer: Berlin, Germany, 2014; pp. 50-61.

78. Garrick, D.; Whitten, S.; Coggan, A. Understanding the evolution and performance of water markets and allocation policy: A transaction costs analysis framework. Ecol. Econ. 2013, 88, 195-205. [CrossRef]

79. Olson, M. The Logic of Collective Action: Public Goods and the Theory of Groups; Harvard University Press: Cambridge, MA, USA, 1965.

80. Pahl-Wostl, C. A conceptual framework for analysing adaptive capacity and multi-level learning processes in resource governance regimes. Glob. Environ. Chang. 2009, 19, 354-365. [CrossRef]

81. McCann, L.; Colby, B.; Easter, K.W.; Kasterine, A.; Kuperan, K.V. Transaction cost measurement for evaluating environmental policies. Ecol. Econ. 2005, 52, 527-542. [CrossRef]

82. Timmerman, J.G.; Langaas, S. Water information: What is it good for? The use of information in transboundary water management. Reg. Environ. Chang. 2005, 5, 177-187. [CrossRef]

(C) 2016 by the authors; licensee MDPI, Basel, Switzerland. This article is an open access article distributed under the terms and conditions of the Creative Commons by Attribution (CC-BY) license (http:/ / creativecommons.org/licenses/by/4.0/). 